OPEN ACCESS

Citation: Luana Russo, Mark Franklin, Stefanie Beyens (2020) Clarity of voter choices: neglected foundation for ideological congruence. Quaderni dell'Osservatorio elettorale - Italian Journal of Electoral Studies 83(2): 3-13. doi: $10.36253 /$ qoe-9836

Received: October 1, 2020

Accepted: November 30, 2020

Published: January 23, 2021

Copyright: (c) 2020 Luana Russo, Mark Franklin, Stefanie Beyens. This is an open access, peer-reviewed article published by Firenze University Press (http://www.fupress.com/qoe) and distributed under the terms of the Creative Commons Attribution License, which permits unrestricted use, distribution, and reproduction in any medium, provided the original author and source are credited.

Data Availability Statement: All relevant data are within the paper and its Supporting Information files.

Competing Interests: The Author(s) declare(s) no conflict of interest.

\section{Clarity of voter choices: neglected foundation for ideological congruence}

\author{
Luana Russo ${ }^{1, *}$, Mark N. Franklin ${ }^{2}$, Stefanie Beyens ${ }^{3}$ \\ ${ }^{1}$ Political Science, Maastricht University, Maastricht, Netherlands, 0000-0002-1237-7310 \\ ${ }^{2}$ Political Science, Trinity College Connecticut, Hartford, USA, 0000-0002-9527-7410 \\ ${ }^{3}$ School of Governance, Utrecht University, Utrecht, Netherlands, 0000-0003-0446-7292 \\ ${ }^{\star}$ Corresponding author. E-mail: 1.russo@maastrichtuniversity.nl
}

\begin{abstract}
Ideological congruence between voters and governments is desirable, the wisdom goes, because it implies enactment of policies close to those preferred by voters. Party polarization plays a paradoxical role here: more polarization reduces voter-government congruence if parties making up a government move away from the center-ground where most individual voters are located; yet increasing polarization permits those governments' policies to become more distinct in the eyes of voters. This paper investigates how political system clarity helps to resolve this paradox. We examine the interplay of several sources of clarity and, in particular, of the joint role of party and voter polarization. We argue and find that, if polarization of survey respondents increases in step with party polarization, this provides clarity that can override party polarization's negative effect on voter-government congruence. But other types of clarity also play important roles in accounting for the range of values that congruence takes on.
\end{abstract}

Keywords. Ideological congruence, electoral clarity, polarization.

\section{INTRODUCTION}

Ideological congruence between individual voters and their elected governments is crucial for well-functioning representative democratic systems. The argument from democratic theory states that this type of congruence indicates policy-making in line with the voter preferences, what Pitkin (1967) called substantive representation. And past research has shown that voters themselves like it, as ideological congruence is one of the most reliable predictors of satisfaction with democracy (Kim 2009; Ferland 2016). Yet ideological voter-government congruence does not appear out of nowhere, nor is it the result of just one feature of the electoral system. Rather, Golder and Ferland (2018) argue that the type of congruence we are dealing with in this paper, proximity on the left-right ideological axis between individual voters and parties making up the government, is the end result of a number of stages in the translation of voters' preferences into votes, votes into seats, and seats into government policy. We are interested particularly, but not unique- 
ly, in the role played by party system polarization and its seemingly paradoxical effects on congruence.

Much controversy surrounds the question of how the polarization of party systems ${ }^{1}$ might affect ideological congruence between individual voters and the parties making up their governments (Belchior 2013; Dalton and Anderson 2011; Powell 2013). For example, if all parties are competing for the center-ground (Downs 1957), then party polarization will be close to zero, as all parties will aim to attract the same voters, and it will make little difference which party or parties win office. Viewed in this light, more party polarization will increase the distinctiveness of policies offered by different parties and will make it easier for voters to choose a party close to their preferences. This reasoning finds some confirmation when we look at studies of satisfaction with democracy: "when party systems offer more policy choices that are proximate to . . . voter positions, satisfaction increases" (Ezrow and Xezonakis 2011, 1153). But the same study also finds that, if parties (and, by implication, governments formed by those parties) $)^{2}$ move too far from the ideological center, satisfaction is reduced (Ezrow and Xezonakis 2011, 1165), perhaps due to reduced ideological congruence between centrist voters and more polarized government parties (Cf. Powell 2013).

This raises the question: how much party polarization is enough to ensure meaningful distinctions among parties without incurring deleterious consequences for ideological congruence? We suggest a previously unanticipated role for voter polarization in mitigating the ill-effects of party polarization. We argue that a joint increase in party and voter polarization can facilitate joint 'sorting' of voters and parties (as will be explained) in terms of their left-right positions, injecting a degree of clarity into the choices facing voters. We expect this clarity to promote ideological (left-right) congruence between voters and governments (as will also be explained). And we will show that, if voter polarization does increase in step with party polarization, this indeed improves ideological congruence between voters and the parties making up their governments.

Still, clarity in terms of distinctiveness of parties and of voter preferences for those parties is only one type of clarity and perhaps not the most important one. Indeed, more than minimal polarization may only be needed if other sources of clarity are absent. Such addi-

\footnotetext{
${ }^{1}$ When we mention party polarization, we refer to the polarization of the party system as conceptualized by Dalton (2008), unless otherwise noted. Our data section has details.

${ }^{2}$ We address problems arising from the party/government distinction in our theory section.
}

tional sources of clarity in the choice between parties include (2) government status - whether it controls a majority of legislative seats - and (3) party system size the effective number of parties - as well as (4) a component that Powell and Whitten (1993) referred to as clarity of responsibility but that we re-conceptualize as the size of the party most likely to gain control of the legislature (that is to say: the size of the largest party). This fourth type of clarity was originally seen as a basis for government accountability, but we elaborate its theoretical underpinnings so as to refocus them from accountability to choice. We name the resulting measure 'electoral clarity'.

We find that, when all four of these sources of clarity in the choice between parties are taken in conjunction, we are able to account for close to the full range of values that ideological congruence (left-right proximity between voters and their governments) takes on empirically, at least in European political systems - the venue for our research.

In the theoretical section we elaborate our argument with reference to earlier findings and explicate the link between clarity and polarization (both of the party system and among voters) as well as the link between clarity and ideological congruence (between individual voters and the parties making up their governments). We proceed by formulating our hypotheses and describing our data. We then examine the effects of polarization and other sorts of clarity on congruence. We conclude with a discussion of our findings.

\subsection{Theory and argumentation (1): how clarity in party} choice can overcome polarization's deleterious effects on congruence

Congruence is an important dependent variable in political science research (see Golder \& Ferland 2018 for a survey of the different conceptualizations of congruence), as it is widely held that democratic governance is enhanced by the enactment of policies as close as possible to those preferred by the median voter (Powell and Vanberg 2000). This expectation occurs at the aggregate level. And, although our focus in this paper is also on the circumstances in which election outcomes provide good representation, our topic calls for individual-level data - the level most appropriate for measuring congruence between individual preferences and party offerings and the only level at which we can measure voter polarization. $^{3}$ At the individual level our research interest

\footnotetext{
${ }^{3}$ We treat the two types of polarization as distinct concepts (in our data they correlate only 0.05 - see our online appendix Table B3), with par-
} 
translates into an expectation that individual voters will more strongly support governments that enact policies close to their own preferences. ${ }^{4}$ In our argumentation and findings we thus focus on either or both of these levels according to which is most appropriate.

Returning to the system level, it is also widely assumed that polarization of the party system has illeffects on the will and capacity of political parties to cooperate in enacting legislation (Barber and McCarty 2015; McCarty 2016; Kim and Urpelainen 2017). This could make it hard for governments in polarized party systems to implement the policy proposals responsible for attracting their supporters, limiting ideological congruence between government parties and their voters. However, it is not clear how much polarization would be needed in order to bring this negative scenario into being and, as already mentioned, lower but still positive levels of polarization may be highly desirable. ${ }^{5}$

Some scholars working on polarization in the American context draw attention to potentially positive effects of what they call 'sorting. ${ }^{6}$ Sorting of legislative parties yields greater differences between those parties and lesser differences within each of them, leading those parties to become more distinctive in their policy offerings. Such a development facilitates parallel sorting of voters into those whose preferences are closer to one party than to another (Hetherington 2009). This could mean, Hetherington (2001) argues, that polarization may have moved American parties into more distinctive ideological positions, clarifying choices for voters, with beneficial consequences for congruence (Hetherington 2009, 427). There is no reason why this clarifying effect of party polarization should not also occur in multi-party European contexts.

In the US literature on voter polarization, one study finds a small yet significant connection between elite/ party polarization and voter consistency (the coherence of both Republican and Democratic supporters): the more polarized the political elites are, the more voters

ty polarization capturing the supply side of electoral politics and voter polarization the demand side.

${ }^{4}$ It is of course possible that aggregate expectations, such as those of Powell and Vanberg (2000), would not be reflected at the individual level; but the theoretical basis for Powell's supposition should apply at either level and our findings suggest conformity in this respect.

${ }^{5}$ A large literature addresses the question whether party polarization itself produces voter polarization but that debate is outside the remit of this paper (cf. Spoon and Klüver 2015). We are not here postulating any causal linkage, just investigating possible consequences of joint movement in the measures.

${ }^{6}$ It is important to note that U.S. measures of party polarization differ from Dalton's measure, which we employ (footnote 11), because they focus rather on within-party cohesion than on between-party differences (e.g. Aldrich 2012, who uses roll-call data; cf. Schlesinger 1985). participate in party cue-taking (Levendusky 2010), with consequences for sorting and confirming the beneficial outcome that Hetherington (2009) anticipated. Having clarity as to where parties stand on a range of issues allows individual voters to 'vote correctly' according to their preferences (Lau and Redlawsk 1997) - which is another way of saying that clarity lets voters sort themselves, in relation to party stances, according to their (the voters') policy preferences. Because there are multiple party locations, as voters sort themselves according to those locations they will ipso-facto become less centrist, distributing themselves more widely across the span of left-right locations and helping to address a paradox, alluded to above, that we now bring into focus.

Any supposed link between party polarization and congruence runs into Powell's (2013) suggested impediment: party polarization may simultaneously stand in the way of congruence due to increasing distance of more polarized parties from centrist voters. At the same time, little meaningful sorting of voters can occur if most voters occupy the same center-ground. This latter insight is our ticket to resolving this apparent paradox. To this end we want also to study polarization in the electorate. If voter polarization rises in step with party polarization, then appropriate sorting might avert the negative effects we would otherwise expect.

A problem for researchers studying the interplay of polarization and congruence is that, while comparative studies of polarization focus on parties or voters, congruence studies such as this one tend to focus on governments and voters. For obvious reasons, US researchers often find no need to distinguish between party-voter congruence on the one hand and government-voter congruence on the other; but researchers who focus on countries that frequently see multi-party coalition governments must address the distinction, as we now do.

It is true that, even if voters sort themselves 'correctly' into camps that match with the ideologies of different parties, this is not the same as voters sorting themselves into camps that match with the ideologies of different potential coalition governments. Still, such sorting into party camps may yet be a necessary pre-requisite for ideological congruence between individual voters and parties that are members of such a coalition government. It is widely assumed that coalition governments reflect the policies of their member parties, and this assumption is confirmed in much recent work on coalition formation and policy-making (e.g. Duch et al. 2009; Armstrong and Duch 2010; Hobolt and Karp 2010; Moury 2013; Fortunato and Stevenson 2013; Jungblut 2017). Certainly, in the absence of some such mechanism for linking clarity of party choices to voter-government congruence, 
our research design would not yield the sensible findings that we are able to report.

\subsection{Theory and argumentation (2): effects of other types of clarity for party choice}

If clarity in party stances due to party polarization (along with appropriate voter polarization) facilitates ideological congruence between individual voters and government parties, then other sources of clarity in party choices may also be important. Indicators of such additional sources of clarity would need to be included in models of ideological congruence if effects of voter sorting were to be properly specified. We conceptualize such additional sources of clarity as comprising what we call 'Political system clarity,' a multifaced concept that needs to be carefully unpacked.

We start from the obvious need for voters to be able to discern the policy positions taken by each party of relevance to them, if those voters are to select a party with good prospects of advancing their policy preferences. We see major potential obstacles in the way of voters' abilities to readily assess party qualities. Some of these (party system size and government status) have been identified as providing opportunities for increasing voter satisfaction if the obstacles are minimized (perhaps because small party systems and majority governments facilitate ideological congruence between voters and their governments). Another (electoral clarity) has figured rather in studies of economic voting and in turnout studies (though sometimes under other names). Figure 1 shows the distinct elements that comprise the composite notion of Political System Clarity (and their relationships with ideological congruence).

It is evident that minority cabinets impede clarity of choices because of the difficulties they have enacting any policies (Christiansen 2018; Plescia and Kritzinger 2017), making it hard for voters to know to what extent such cabinets should be blamed for policy shortcomings. Choices should thus be easiest where majority governments clarify responsibility for government policies (Christmann and Torcal 2018). ${ }^{7}$ Regarding party system size, it is also obvious that the more parties there are competing for votes the harder it will be for voters to become acquainted with their relative strengths and weaknesses (Kroh 2009). Simply keeping track of differences between their policy proposals will be increasingly challenging as party system size increases (Farhang and

\footnotetext{
${ }^{7}$ These authors also suggest that smaller coalition governments would be similarly beneficial, but we found no significant effect of this variable on voter-party left-right congruence.
}

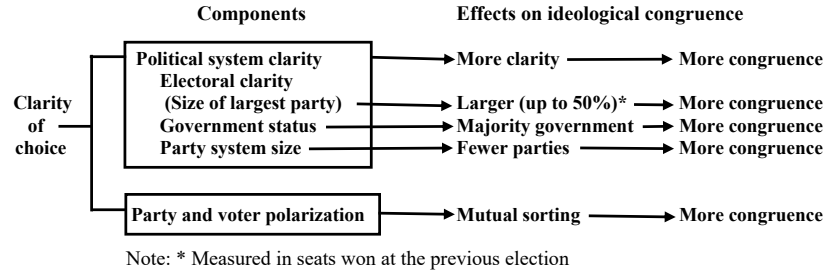

Figure 1. Sources of clarity in party choice and their effects on ideological congruence.

Yaver 2016; Martini and Quaranta 2015). Moreover, the more parties there are, the greater the need for ruling coalitions (Downs 1957), which affects not only government representativeness and effectiveness (Berggren et al. 2004) but also clarity (Anderson 2000). A final component of political system clarity is electoral clarity to which we now turn.

In a country where coalition governments are the norm, voters would need to know a great deal about likely coalition preferences of the parties on offer (Fortunato and Stevenson 2013) in order to be able to make sensible use of their vote. This problem will evidently be particularly acute to the extent that the parties are small ones. In majoritarian systems, some scholars suggest, the problem would be less (Powell and Whitten 1992; Powell 2013; Sanders et al. 2014). One reason these scholars point to is that such systems tend to have fewer parties; but another seldom-mentioned reason is because in such systems there is almost always at least one large party, and voters can focus their attention on whether to vote for that party or for (one of) the alternative(s). But this ability to focus on a large party as opposed to its alternatives is not just a feature of majoritarian systems. Many proportional systems are also characterized by having a large party: a party that, if in government, will dominate any coalition of which it forms part and that, if in opposition, will define the most likely alternative to the government in power. So we contend that the active ingredient in majoritarian systems when it comes to their clarity is the size of the largest party, measured in terms of its likelihood of gaining control of the legislature - an ingredient we also find in proportional systems. Since legislative control is achieved with 50 percent of seats, what matters is the gap between the party's size in seats and 50 percent. ${ }^{8}$ This measure (unlike the electoral system measure that was its precursor) has the great advantage of varying from one

\footnotetext{
${ }^{8}$ The smaller the gap, the higher the clarity. Evidently if the second-largest party also holds close to half the seats then we have a two-party system, often assumed to have what we see as high clarity. Parties controlling more than half the seats are rare (footnote 12). The small number of two-party systems and over-sized parties in Europe make it unprofitable for us to make these further distinctions.
} 
election to another and not just between countries. It has been widely used in turnout studies (Franklin 2004; Johnson et al. 2007; Franklin and Hobolt 2011; Vowles et al. 2015; Franklin 2020), as a measure of the extent of effective electoral competition, but never (to the best of our knowledge) in studying party choice. In order to avoid a cumbersome phrase when referring to this measure we will generally refer to it simply as electoral clarity.

Although all of these variables have previously been seen as relevant to voter decision-making, only in regard to electoral clarity do scholars regularly explain this relevance in terms of the role the variable plays in clarifying voter choices - and then only in studies of economic voting and some turnout studies.

\section{HYPOTHESES}

We start from the apparent paradox mentioned earlier. Powell (2013) suggests that parties in a more polarized party system must logically be more distant from centrist voters. However, Powell does not consider what might happen if voters themselves were also to become more polarized. Evidently, should voters become sufficiently polarized and this were accompanied by appropriate sorting, there would be no logical impediment to congruence between voters and parties being maintained or even enhanced with rising party polarization, as already explained.

On this basis, our first hypothesis has two parts:

H1a: Party polarization has a negative effect on ideological congruence between voters and governments,

H1b: unless voter polarization increases in step with party polarization, stimulating voter sorting and improving clarity of voter choices.

Other sources of political system clarity should also play important roles.

H2: Smaller party systems, majority governments and electoral clarity also contribute to clarity of choices, further increasing ideological congruence.

These sources of clarity provide additional (or alternative) sources of ideological congruence between voters and governments. Given that our measure of electoral clarity is a new contribution to conceptions of political system clarity, we need to document its potency:

H3: Among components of political system clarity, electoral clarity makes a notable contribution.

\section{DATA AND METHOD}

In order to test our hypotheses, we rely on Eurobarometer (EB) data and on the ParlGov database (see
Appendix A below). Our cross-sectional time-series starts in 2004 because this is when a large wave of 14 new countries joined the Eurobarometer universe, yielding coverage of 27 countries (our online Appendix B has details). ${ }^{9}$ We end in 2016 - the latest year for which all clarity variables are available. From each of the sixmonthly EBs asking suitable questions we selected only countries that had held an election during the six months before each survey, for a total of 75 elections (Appendix A has details). Unfortunately a question crucial to our analysis (left-right self-placement) was not asked in every EB. Deleting studies from which that question was missing left us with 71 usable EBs (detailed in our online Appendix B).

Our dependent variable, Ideological Congruence pairs the Eurobarometer indicator of respondent leftright position with the ParlGov indicator of party position, both using the same ten-point scale, and takes the inverse of the absolute difference between each respondent's position and the weighted average of government party positions (from expert surveys listed in Appendix A), thus focusing on the proximity between voters and governments. Weighting is by the size of each party, measured as the proportion of legislative seats won at the election immediately prior to the survey. ${ }^{10}$

Our inputs are Party Polarization, Voter Polarization and three indicators of political system clarity. Party Polarization is measured by the Dalton $(2008,906)$ index, derived from the same ParlGov measure of party position as for ideological congruence, and weighted in the same way. ${ }^{11}$ Voter Polarization is the standard deviation of EB respondents' left-right self-placements (cf. Ezrow et al., 2014). Electoral Clarity is coded as the inverse proportion absolute gap between half the legislative seats and the proportion of seats held by the largest party in the legislature at the election concerned. ${ }^{12}$

\footnotetext{
${ }^{9}$ Starting earlier would increase the weight of established political systems, possibly vitiating the power of a research design involving a wide range of different types of polity. We restrict our data to surveys conducted within 6 months of an election for reasons given in Appendix A. ${ }^{10}$ Findings are no different if parties are weighted by seats in the governing coalition. Left-right position is widely used for measuring both polarization and congruence. For a survey see Kroh (2009). Duch et al. (2008) find, by analyzing 86 voter preference surveys from 30 countries, that left-right position is by far the dominant determinant of party choice.

${ }^{11}$ Dalton (2008: 906) describes the index as "PI = SQRT $\left\{\sum\right.$ (party vote sharei $)^{\star}\left([\text { party L/R scorei - party system average L/R score]/5) })^{2}\right.$ \}" where the i subscript represents individual parties. This index is comparable to the standard deviation of a distribution and is similar to statistics used by other scholars. Its value is 0 when all parties occupy the same position on the left-right scale and 10 when their weights are evenly split between the scale's two extremes.

${ }^{12}$ A positive gap between size of largest party and half the legislative seats is seldom of more than trivial magnitude in Europe; but any such
} 
Our final two variables are party system size (the effective number of parties) and government status (whether the government commanded a majority of seats). ${ }^{13} \mathrm{We}$ see both of these variables as contributing, along with electoral clarity, to what we call political system clarity (Appendix A has details). Though somewhat interrelated, they present no risk of multicollinearity (see online Appendix B).

We have no measure of 'sorting' but significant effects of the interaction between party and voter polarization will strongly suggest the operation of some such mechanism.

Because our focus is on determinants of congruence, an individual-level concept, we employ survey data to measure our dependent variable (as well as one critical independent variable, voter polarization); but because our interest is in contextual effects on congruence we include no other individual level measures (such as education or political interest) that might influence individual abilities to vote correctly. These would only complicate an already elaborate research design.

In order to make the interpretation of the final models more intuitive, we rescaled all the continuous variables onto 0-1 scales, to match our dummy variable indicator for majority cabinets; and inverted them where necessary so that higher values should predict higher clarity (Appendix Tables A1 and A2, below, have details).

Regarding modelling strategy, we employ a twolevel mixed effects regression model, with country at the higher level and respondent at the lower level. We specify no level for election year because some of our controls only vary at that level. Some would argue that this feature of our data calls for a fixed effects regression model, which is presented in online Appendix B. The coefficients are almost identical. All effects are significant at the 0.001 level or better.

\section{RESULTS}

To test our hypotheses Table 1 contains a model focused on our suggested solution to Powell's (2013) seeming paradox regarding ideological congruence between voters and government. It shows that the negative effect of party polarization expected by Hla (row 1 ) is by far overridden should voter polarization rise in

deviation suggests non-competitive elections that would make it harder for voters to achieve desired left-right proximities in much the same way (if for different reasons) as a negative gap.

${ }^{13}$ We code party system size (available only until 2016) as the number of electoral parties, capped at 10 (and linearized by taking the square root). See Appendix A, below for details.
Table 1. Effects of polarization on voters' ideological congruence with government left-right position, controlling for aspects of political system clarity (mixed effects model).

Outcome: ideological congruence

\begin{tabular}{lcc} 
Inputs & Coef & (s.e.) \\
\hline 1) Party polarization (0-1) & $-0.21(0.02)$ \\
2) Voter polarization (0-1) & $-0.06(0.02)$ \\
3) Party polarization * voter polarization & $0.70(0.06)$ \\
4) Electoral clarity (1 - largest party abs. proportion & & \\
gap from 50\%) & $0.19(0.01)$ \\
5) Majority government (0, 1=yes) & $0.05(0.01)$ \\
6) Party system clarity (1 - proportion of max n of & \\
parties <=10) & $0.29(0.02)$ \\
7) Intercept & $0.43(0.03)$ \\
Random-effect parameters & \\
$\quad$ Variance of country intercepts & $0.02(0.00)$ \\
$\quad$ Residual variance & $0.03(0.00)$ \\
Log-likelihood & 9521.05 \\
Observations & 37,296 \\
Number of elections & 27
\end{tabular}

Note: All coefficients significant at $\mathrm{p}<0.001$, one-tailed.

step with party polarization (row 3), confirming H1b. ${ }^{14}$ Other sources of clarity also show the effects expected of them, confirming H2. In particular, electoral clarity shows effects that are greater by a factor of 4 than those of majority government (confirming H3). The robustness of these findings is suggested by a fixed effects replication in online Appendix B, Table B4.

Figure 2 uses the estimates from Table 1 to graph the levels of voter-government left-right congruence predicted by the interaction of party polarization and voter polarization, separately for high and low clarity contexts. So different levels of clarity locate the same three slopes at different levels on the graph, showing how our model's predictions encompass close to the full range of values that congruence takes on. Clarity of all three types (electoral, government, and party system size) are set to values least conducive to congruence for low clarity contexts and to their opposite extremes for high clarity contexts. ${ }^{15}$

The graph demonstrates several important points about effects on congruence. ${ }^{16}$ First, any increase in

\footnotetext{
${ }^{14}$ When we use the word "effect" we do not mean to imply evidence of causation.

${ }^{15}$ Online Appendix B supplies another robustness check (Figure B4) in which predictions are graphed that are based on data from which cases containing outlying values of polarization have been removed. The resulting picture is very similar to that shown in Figure 2, demonstrating that these findings do not result from outlier leverage.

${ }^{16}$ The underlying density plot for congruence is repeated in vertical format in online Appendix B, Figure B1. A density plot for voter polarization is shown in the same appendix, Figure B2.
} 


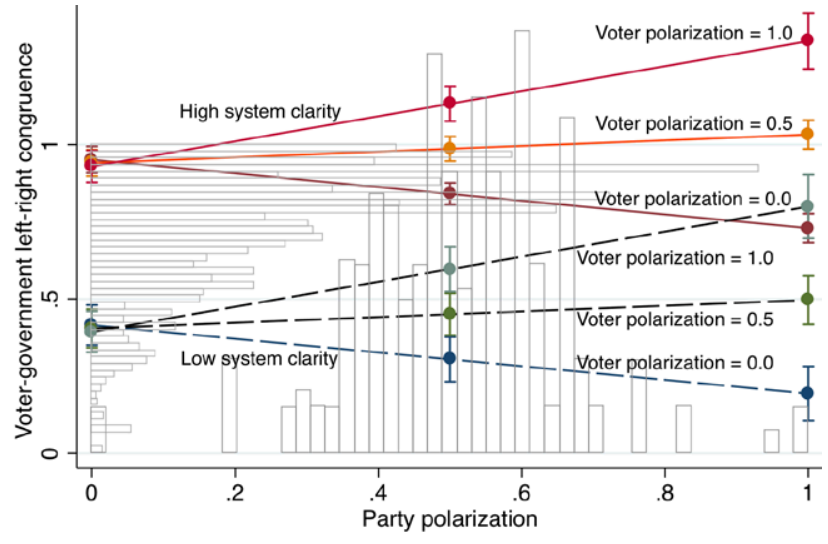

Figure 2. Left-right congruence between voters and governments predicted by the interaction of party polarization and voter polarization at two different levels of political system clarity (spikes show $99 \%$ confidence intervals) overlaying densities for each axis.

party polarization has negative effects unless voter polarization stands close to or above its mid-point in our data (the lowest trace in each group of traces slopes downwards). ${ }^{17}$ With higher than medium voter polarization, increasing party polarization can be beneficial to left-right congruence (the other traces slope upwards). The joint effects of increases in both types of polarization overcome the paradox suggested by Powell's (2013) insight (at least with European survey data), reinforcing the confirmation of $\mathrm{H} 1 \mathrm{~b}$ that was already seen in Table 1 .

The palpably greater levels of congruence seen for high system clarity than for low system clarity confirm the importance of political system clarity for congruence (H2). A substantial share of clarity's systemic effects is attributable to our new measure of electoral clarity (row 4 of Table 2), confirming H3. Even so, in contexts of low system clarity, high party polarization accompanied by high voter polarization go far towards mitigating low system clarity's debilitating effects on congruence (the highest low-clarity trace actually overlaps the lowest high-clarity trace at the far right of Figure 2). This finding suggests that suitable combinations of party and voter polarization can themselves provide a good degree of clarity to otherwise opaque political systems - a sort of stand-in for political system clarity - and that moderately high congruence can result, though this happens infrequently (see Figure B3 in our online Appendix B).

We also see that the logical requirement of a minimum level of party polarization is satisfied in a very

\footnotetext{
${ }^{17}$ Unlike party polarization, voter polarization is somewhat skewed towards low values (see online Appendix B, Figure B2), so it makes sense to focus on upward deviations from the norm.
}

high proportion of the elections that we study (the underlying density plot for party polarization in Figure 2 shows 84 percent of cases with party polarization above 0.4$).^{18}$

Curiously, Figure 2 shows predicted values of voter-government congruence that exceed the maximum value congruence can take on. ${ }^{19}$ This could result from a variety of circumstances but robustness tests in our online Appendix B suggest trade-offs occurring at specific elections between system clarity and different types of polarization. There are thus a variety of ways in which elections can attain the highest levels of left-right congruence between voters and governments.

\section{DISCUSSION}

In this paper we have investigated how clarity of choices helps to overcome various obstacles that voters may find in choosing parties that will form governments ideologically close to them in left-right terms. We show that there are various types of clarity of which the most difficult to evaluate, both conceptually and operationally, is the clarity that can come from the interplay of voter and party polarization. We asked how it is possible to get good levels of ideological congruence between voters and governments despite the need for some party polarization whose effects (based on existing research) should be negative. The answer to this puzzle turns out to be straightforward. Voter polarization can offset the negative effects of any party polarization that may be present. This offsetting presumably comes into being through the workings of a previously theorized sorting mechanism - workings that clarify the choices voters need to make between the parties they could support - and manifests itself through effects on congruence. Such manifestations have not previously been observed outside the United States.

The effects of voter polarization are, however, contingent. Positive effects on voter-government left-right congruence are only seen where there is elevated party polarization. Any attempt to assess effects of voter polarization must take the level of party polarization into account. Otherwise inconsistent effects will likely be observed.

Our new understanding of the clarifying effects of voter and party polarization contribute to a more general understanding of the ways in which various aspects

\footnotetext{
${ }^{18}$ Note that the zero point for polarization of each type is set not by some absolute standard but by the lowest level of polarization actually found in our data.

${ }^{19}$ From a purely arithmetic standpoint these out-of-bounds predictions could be eliminated by subjecting the outcome variable to a logarithmic transformation. But the resulting graph would not make the point we want to make regarding redundancy among predictors.
} 
of clarity assure voter-government left-right congruence. Aspects of clarity, taken together, between them account for a range of outcome values that come within about 0.2 of spanning the entire range of values that congruence takes on in practice. The fact that predicted values can exceed maximum congruence by a considerable margin suggests a degree of redundancy in the effects we measure, which provide more than one route to maximum congruence. ${ }^{20}$

In arriving at these findings, we have also to a considerable extent succeeded in unpacking the concept of political system clarity into components that all play important roles. Two of these (majority governments and low effective numbers of parties) have figured in earlier theorizing of relevance to voter-government congruence; but an important role is played by a measure not previously used in such studies: the size of the largest party relative to the point at which it would control the legislature. Such control is achieved when a party controls half the legislature's seats. Proportion absolute gap between largest party size in seats and $50 \%$ of total seats is an indicator of clarity that incorporates what we take to be the active ingredient in Powell and Whitten's (1993) insight about the clarity imparted by majoritarian electoral systems: they tend to yield party systems with at least one large party. But that active ingredient can be found in electoral systems of all types. Proportional representation does not rule out parties comparable in size to the largest parties in majoritarian systems. And the effects of this variable are highly significant and of comparable magnitude to other, previously theorized, cognate effects.

Our new measure of electoral clarity thus makes an important contribution to our elucidation of the paradoxical foundations for left-right congruence between individual voters and their governments.

\section{REFERENCES}

Aldrich, John. 2012. "Partisan Polarization and Satisfaction with Democracy." In Daniel M. Shea and Morris P. Fiorina, eds., Can We Talk?: The Rise of Rude, Nasty, Stubborn Politics. Pearson Higher Ed., pp. 121-141. Anderson, Christopher J. and Guillory, Christine A. 1997. "Political institutions and satisfaction with democracy: A cross-national analysis of consensus and majoritarian systems." American Political Science Review 91(1): 66-81.

\footnotetext{
${ }^{20}$ There are of course additional effects on voter-government congruence, not included in our models, that could produce maximum (minimum) levels of congruence even when our variables do not take on their most extreme values (see, e.g. Pedrazzani and Segatti 2020).
}

Armstrong, David and Raymond Duch (2010) "Why can voters anticipate post-election coalition formation likelihoods. Electoral Studies 29(3): 308-315

Barber, Michael and McCarty, Nolan. 2015. "Causes and consequences of polarization." In Jane Mansbridge and Cathie Jo Martin, eds., Political Negotiation: A Handbook. Washington, DC: Brookings Institution Press, pp. 37-90.

Belchior, Ana Maria. 2013. Explaining left-right party congruence across European party systems: a test of micro-, meso-, and macro-level models. Comparative Political Studies 46(3): 352-386.

Berggren, Heidi M, Furgate, Gregory A., Preuhs, Robert R., \& Still, Dennis R. 2004. "Satisfied? Institutional determinants of citizen evaluations of democracy." Politics \& Policy 32(1): 72-96.

Christiansen, Flemming Juul. 2018. "Denmark: strengthened opposition, yet high levels of cooperation." In Elisabetta De Giorgi and Ilonszki Gabriella, eds., Opposition Parties in European Legislatures: Responsiveness Without Responsibility? Routledge.

Christmann, Pablo and Torcal, Mariano. 2018. "The effects of government system fractionalization on satisfaction with democracy." Political Science Research and Methods 6 (3): 593-611.

Dalton, Russell J. 2008. "The quantity and the quality of party systems, Party system polarization, its measurement, and its consequences." Comparative Political Studies 41(7): 899-920.

Dalton, Russell J.; Anderson, Christopher J. (ed.). 2011. Citizens, context, and choice: how context shapes citizens' electoral choices. Oxford University Press.

Downs, Anthony. 1957. "An economic theory of political action in a democracy." Journal of political economy 65(2): 135-150.

Duch, Raymond, Jeff May and David Armstrong. 2009. "Coalition-directed Voting in Multiparty Democracies," American Polical Science Review 104(4): 698-719.

Ezrow, Lawrence, and Xezonakis, Georgios. 2011. "Citizen satisfaction with democracy and parties' policy offerings." Comparative Political Studies 44(9): 11521178.

Ezrow, Lawrence, Tavits, Margit, and Homola, Jonathan. 2014. "Voter polarization, strength of partisanship, and support for extremist parties." Comparative Political Studies 47(11): 1558-1583.

Farhang, Sean, and Yaver, Miranda. 2016. "Divided government and the fragmentation of American law." American Journal of Political Science 60(2): 401-417.

Ferland, Benjamin. 2016. "Revisiting the ideological congruence controversy." European Journal of Political Research 55(2): 358-373. 
Fortunato, David and Stevenson, Randolphe T. 2013. "Perceptions of partisan ideologies: The effect of coalition participation." American Journal of Political Science 57(2): 459-477.

Franklin, Mark N. 2004. Voter turnout and the dynamics of electoral competition in established democracies since 1945. Cambridge: Cambridge University Press.

Franklin, Mark N. 2020. "Consequences of lowering the voting age to 16: lessons from comparative research" in Jan Eichorn and Johnnes Bergh (eds.) Lowering the Voting Age to 16: Learning from Real Experiences Worldwide. London: Palgrave Macmillan.

Franklin, Mark N. and Hobolt, Sara B. 2011. "The legacy of lethargy: How elections to the European Parliament depress turnout." Electoral Studies 30(1): 67-76.

Golder, Matt, and Benjamin Ferland. 2018. "Electoral Systems and Citizen-Elite Ideological Congruence" in Erik Herron, Robert Pekkanen, and Matthew Shugart (eds.) The Oxford Handbook of Electoral Systems. Oxford: Oxford University Press.

Golder, Matt, and Jacek Stramski. 2010. "Ideological Congruence and Electoral Institutions." American Journal of Political Science 54(1): 90-106.

Hetherington, Marc J. 2001. "Resurgent mass partisanship: The role of elite polarization." American Political Science Review 95(3): 619-631.

Hetherington, Marc J. 2009. "Putting polarization in perspective." British Journal of Political Science, 39(2): 413-448.

Hobolt, Sara and Jeffrey Karp. 2010, "Voters and Coalition Governments” Electoral Studies 29 (3), 299-307.

Johnston, Richard, Matthews, J. Scott, Bittner, Amanda. 2007. "Turnout and the party system in Canada, 1988-2004." Electoral Studies 26(4): 735-745.

Jungblut, Jens. 2017. "From preferences to policies in coalition governments-Unpacking policy making in European higher education." Public Policy and Administration 32(4): 323-348.

Kim, Myunghee. 2009. "Cross-national analyses of satisfaction with democracy and ideological congruence." Journal of Elections, Public Opinion and Parties 19(1): 49-72.

Kim, Sung Eun, and Urpelainen, Johannes. 2017. “The polarization of American environmental policy: A regression discontinuity analysis of Senate and House votes, 1971-2013." Review of Policy Research 34(4): 456-484.

Kroh, Martin. 2009. “The ease of ideological voting: Voter sophistication and party system complexity" in HansDieter Klingemann (ed.) The Comparative Study of Electoral Systems. Oxford: Oxford University Press, pp. 220-236.
Lau, Richard R., and Redlawsk, David P. 1997. "Voting correctly." American Political Science Review 91(3): 585-598.

Levendusky, Matthew S. 2010. "Clearer cues, more consistent voters: A benefit of elite polarization." Political Behavior 32(1): 111-131.

Martini, Sergio and Quaranta, Mario. 2015. "Finding out the hard way: Uncovering the structural foundations of political dissatisfaction in Italy, 1973-2013." West European Politics 38(1): 28-52.

McCarty, Nolan. 2016. "Polarization, Congressional Dysfunction, and Constitutional Change." Ind. L. Rev. 50: 223.

Moury, Catherine. 2013. Coalition Government and Party Mandate, London: Routledge.

Pedrazzani, Andrea and Paolo Segatti. 2020. "Responsiveness when parties are 'weak': A candidate-based analysis of voter-party congruence in Europe." Party Politics. doi:10.1177/1354068820968091

Powell, G. Bingham. 2013. "Representation in context: Election laws and ideological congruence between citizens and governments." Perspectives on Politicsn 11(1): 9-21.

Powell, G. Bingham and Vanberg, Georg S. 2000. "Election laws, disproportionality and median correspondence: Implications for two visions of democracy." British Journal of Political Science 30(3): 383-411.

Powell, G. Bingham and Whitten, Guy D. 1993. "A crossnational analysis of economic voting: taking account of the political context." American Journal of Political Science 37(2): 391-414.

Sanders, David, Clarke, Harold, Stewart, Marianne and Whiteley, Paul. 2014. "Output-oriented legitimacy: Individual- and system-level influences on democracy satisfaction." In Jacques Thomassen, ed., Elections and Democracy: Representation and Accountability. Oxford: Oxford University Press, pp. 153-180.

Schlesinger, Joseph A. 1985. "The New American Political Party." American Political Science Review 79(4): $1152-1169$.

Spoon, Jae-Jae, and Klüver, Heike. 2015. "Voter polarisation and party responsiveness: Why parties emphasise divided issues, but remain silent on unified issues." European journal of political research 54(2): 343-362.

Vowles, Jack, Katz, Gabriel, and Stevens, Daniel. 2017. "Electoral Competitiveness and Turnout in British Elections, 1964-2010.” Political Science Research and Methods 5(4): 775-794. 


\section{APPENDIX A: DATA SOURCES AND CODING}

\section{1) Survey data}

Our survey data come from the European Commission's Eurobarometer public opinion surveys (https:// ec.europa.eu/commfrontoffice/publicopinion/index.cfm/ Archive/index ). Our versions were obtained from the GESIS data archive (https://www.gesis.org/en/eurobarometer-data-service/survey-series).

A critical aspect of our research design was to restrict our surveys to those conducted in proximity to a national election. This choice was made because empirically our findings were less reliable (had lower levels of statistical significance) if we moved outside the span of time when memories of recent elections (and leftright stances adopted at the time of those elections) can still be considered reliable. Outside a six-month span, research has shown that memories become degraded by evolving partisanship in light of evolving political circumstances (see van Elsas et al. 2016). Limiting our data in this way left us with 71 EB surveys fielded across 27 European countries between 2004 and 2016 (see our online Appendix B for details).

\section{2) The ParlGov measure of party left-right location:}

Sources for these data are the Chapel Hill expert Surveys (CHES) conducted in 2002, 2006, 2010 and 2014. Original values were rescaled (0-10) before calculating the mean (weighted by party size in seats). The ParlGov codebook reports these values as timeinvariant and they appear to have all been taken from the 2010 CHES survey. However, when we examine the CHES data from surveys most proximate to each of our time-points we find very little variation over time, and the ParlGov data we employ correlates 0.87 with the time-variant CHES data. It makes no substantive difference to our findings which version we employ but those we get from the ParlGov version are more conservative. See (http://www.parlgov.org/documentation/ codebook/\#party).

For party polarization (foootnote 9) we weighted these data by each party's proportion seats.

Voter-government left-right congruence is the difference between a voter's self-placement and the placement in ParlGov data of parties flagged there as being members of the government (again weighted by size of party in seats).

\section{3) Sources for measures of political system clarity}

Data needed to construct our measure of electoral clarity and majority government were taken from the ParlGov data archive (http://www.parlgov.org/documentation/codebook/). Our measure of party system clarity was taken from Golder and Bormann's Democratic Electoral Systems dataset, 1946-2016 (http://mattgolder.com/ files/research/es_v3_codebook.pdf). See (Bormann and Golder 2013). A measure of coalition size evaluated for inclusion in our study and referred to in the main text (footnote 7) was also obtained from the ParlGov data by counting the number of parties flagged as being members of a government.

Table A1. Overview of the variables (original values).

\begin{tabular}{lccccc}
\hline Variable & Obs & Mean & $\begin{array}{c}\text { Std. } \\
\text { Dev. }\end{array}$ & Min & Max \\
\hline Party Polarization & 71 & 0.42 & 0.07 & 0.16 & 0.66 \\
Voters Polarization & 38,124 & 2.19 & 0.32 & 1.50 & 3.19 \\
Voter-government left-right & 38,124 & 0.75 & 2.53 & -7.10 & 7.20 \\
congruence & 71 & 4.98 & 1.52 & 2.01 & 9.62 \\
Number of effective parties & 71 & 0.36 & 0.11 & 0.15 & 0.59 \\
Size of largest party & 71 & 0.47 & 0.33 & 0.00 & 1.00 \\
Majority Government & & & & &
\end{tabular}

Note: Ns shown are valid Ns with listwise deletion when predicting left-right voter-government congruence. For analysis, all variables were rescaled to range from 0 to 1 (see Table B2).

* Party systems with 12 parties were coded 10 to avoid outlier effects (see text following Table B2). There were no 11-party systems.

Number of effective parties in the electorate (ENEP) has a curvilinear effect on congruence, with a steep decline in congruence over the first 8 parties that flattens out thereafter, with some hint of a negative effect with more than 10 parties (cf. Berggren et al. 2004) that, however, does not prove statistically significant in our data because there are so few very large party systems. Given that we have no systems with 11 parties, the few 12-party systems have considerable leverage, so we cap our measure at 10 . The variable is then linearized by taking its square root. All variables were rescaled to range from 0 to 1 and reversed if necessary (by subtracting them from 1) to ensure that positive movements would indicate increasing clarity (see Table A2, below, supplemented by Table B2 in the Online Appendix). 
Table A2. Continuous inputs re-scaled 0-1, inverted and/or capped as necessary.

\begin{tabular}{lccccc}
\hline Variable & Obs & Mean & $\begin{array}{c}\text { Std. } \\
\text { Dev. }\end{array}$ & Min & Max \\
\hline Party Polarization & 71 & 0.19 & 0.17 & 0 & 1 \\
Voters Polarization & 37,296 & 0.26 & 0.16 & 0 & 1 \\
$\begin{array}{l}\text { Voter-government left-right } \\
\text { Congruence }\end{array}$ & 38,124 & 0.75 & 0.19 & 0 & 1 \\
$\begin{array}{l}\text { Number of effective parties } \\
\text { Electoral Clarity (1 - largest party }\end{array}$ & 71 & 0.72 & 0.16 & 0 & 1 \\
$\begin{array}{l}\text { abs gap from 50\%) } \\
\text { Majority government }\end{array}$ & 71 & 0.44 & 0.28 & 0 & 1 \\
\hline
\end{tabular}

Note: Ns shown are valid Ns with listwise deletion when predicting left-right voter-government congruence.

* Capped at 10 parties and linearized (see text).

References for Appendix A that do not appear in the main text's bibliography

Nils-Christian Bormann \& Matt Golder. 2013. "Democratic Electoral Systems Around the World, 19462011." Electoral Studies 32: 360-369.

Van Elsas, E, E Miltenburg and T van der Meer (2016) "If I recall correctly: an event history analysis of forgetting and recalling past voting behavior." Journal of Elections Public Opinion and Parties 26(3): 253-272. 